\title{
Determination of Some Heavy Metals Levels in Funaria Hygrometrica in Dutsinma Town of Katsina State, Nigeria
}

\author{
${ }^{1}$ BATAGARAWA, S M; ${ }^{2 *}$ LAWAL, A O
}

\author{
${ }^{1}$ Chemistry Department, Umaru Musa Yar'adua University, Katsina, Nigeria (e-mail: smuazub@yahoo.com, Tel: +60174599098) \\ ${ }^{2 *}$ Gamma Irradiation Facility, Nuclear Technology Centre, Nigeria Atomic Energy Commission, Sheda. P.M.B. 186, Garki, Abuja, Nigeria. \\ (e-mail: abdulmojeedlawal@yahoo.com, Tel: +234-07034760448).
}

\begin{abstract}
The levels of some heavy metals were determined in Funaria hygrometrica (moss plant) harvested from the streets of Dutsinma town of Katsina State of Nigeria using atomic absorption spectrometry. Over the years the town has witnessed influx of people from neighbouring villages, as a Local government headquarters. The mean level of the metals in the study area varied between $\mathrm{Cd}\left(0.06 \mu \mathrm{gg}^{-1}\right.$ and $\left.0.43 \mu \mathrm{gg}^{-1}\right) ; \mathrm{Cu}\left(1.45 \mu \mathrm{gg}^{-1} \mathrm{and}^{-1} .97 \mu \mathrm{gg}^{-1}\right) ; \mathrm{Fe}\left(81.75 \mu \mathrm{gg}^{-1}\right.$ and $\left.131.48 \mu \mathrm{gg}^{-1}\right) ; \mathrm{Mn}\left(4.13 \mu \mathrm{gg}^{-1}\right.$ and $\left.9.64 \mu \mathrm{gg}^{-1}\right) ; \mathrm{Ni}\left(0.05 \mu \mathrm{gg}^{-1}\right.$ and $\left.0.16 \mu \mathrm{gg}^{-1}\right) ; \mathrm{Pb}\left(1.17 \mu \mathrm{gg}^{-1}\right.$ and $\left.6.40 \mu \mathrm{gg}^{-1}\right)$ and $\mathrm{Zn}^{\mathrm{n}}$ $\left(3.82 \mathrm{\mu gg}^{-1}\right.$ and $\left.7.94 \mu_{g^{-1}}\right)$. The result shows relatively high levels for $\mathrm{Cu}, \mathrm{Fe}, \mathrm{Mn}, \mathrm{Pb}$ and $\mathrm{Zn}$ in the plant. This was attributed to the concentrations of motor vehicles and some industries that have increased in the town over time. Other heavy metals $(\mathrm{Cd}$ and $\mathrm{Ni}$ ) were found in relatively smaller concentrations. The absorption of these metals was related to their concentrations in the atmosphere as a result of industrial and automobile emissions. @ JASEM
\end{abstract}

Heavy metals are widely distributed in the environment and are not biodegradable, hence are not readily detoxified or removed by metabolic activities once they are available in the environment. Environmental pollution by heavy metals is usually as a result of activities related to industrialization, including combustion of fuels, or other temperature driven reactions associated with vehicular performances. $\mathrm{Cd}, \mathrm{Pb}, \mathrm{Cu}$, and $\mathrm{Zn}$ are fuel additives that are released into the atmosphere and carried to the soil through rain and wind (Kho et al., 2007). Although heavy metals are natural components of the environment, metals such as $\mathrm{Pb}, \mathrm{Cd}, \mathrm{Hg}, \mathrm{Ni}$ and $\mathrm{As}$ have no known or reported biochemical importance and their appreciable concentration could become potential lethal hazards (Ademoroti, 1996). A range of these metals found in the environment are harmful to living organisms. Some of them could find their way from plants and animals through food chain to man attacking specific sites or organs of the body and diseases can develop as a consequence of exposure to these substances (Audu and Lawal, 2005).

Many plants and animals have been used to assess environmental pollution and several studies have been reported on the accumulation of environmental pollutants in plants (Kasanen and Venetvaara, 1991). In Israel, for example lichen and higher plant species were exposed near industrial areas in order to detect the accumulation of heavy metals in plants and to assess the impact of these pollutants (Naveh et al, 1979). Tree barks and their leaves remain in the environment for a long period and are sensitive indicators of the environmental contamination with heavy metals, sulphur and fluorine (Ayodele and Ahmed, 1996). Onianwa (2001) and Zechmeister et al. (2005) have independently studied and determined heavy metals using sediments and organisms. But, of all plants, mosses and lichens have been found to be the best bio indicators (Gerdol et al, 2000; Fernandez et al, 2002). This is because these plants grow abundantly in natural habitats, urban areas and industrial locations (Aceto et al. 2003). They have the ability to accumulate heavy metals with high efficiency and low selectivity. Besides, the ability of mosses in this regard could also be attributed to their small size, nakedness, habitat, poikilohydric nature and their high tolerance to different environmental conditions (Csintalan et al. 2005). Generally, bryophytes, especially mosses are ubiquitous as they are equipped with some structural adaptive strategies that enable them to grow successfully where they occur. Moreover their ability to grow on substrates or areas which are inhospitable to higher plants exclude them from intense competition and this gives them an added advantage to serve as good bio indicators (Meenks et al. 1991).

Dutsinma is one of the local government headquarters in Katsina State of Nigeria. It is centrally located in the state. It lies within longitude $7^{\circ} 30^{\prime} \mathrm{E}$ and latitude $12^{\circ} 27^{\prime} \mathrm{N}$, within a topographical drainage of river Karaduwa flowing east west. The vegetation of the area is the savannah type, with more grasses than hard wood trees. The average annual rainfall of the area is $817 \mathrm{~mm}$. The relative humidity is moderate and the temperature varies between $27-35^{\circ} \mathrm{C}$. The town has witnessed influx of people from neighbouring villages, as a Local government headquarters. This has increased the concentrations of motor vehicles and some industries over time. Therefore, this research work was aimed at appraising the concentrations of some heavy metals in Funaria hygrometrica harvested from the streets of Dutsinma 
town to ascertain the level of pollution by this metals. The need to identify bio-indicators in the environment is required as this would reveal the pollution status of man's environment from time to time. This would equally help in identifying the prevailing danger and thus enable man to take necessary step by checkmating the release of such pollutant and advise the government or people on the necessary steps to take so as to enjoy longevity and good health. Therefore, this research work reports the concentration of $\mathrm{Cd}, \mathrm{Cu}, \mathrm{Fe}, \mathrm{Mn}, \mathrm{Ni}, \mathrm{Pb}$ and $\mathrm{Zn}$ in Funaria hygrometrica in Dutsinma town of Katsina State, Nigeria.

\section{MATERIALS AND METHODS}

Analytical reagent (AnalaR) grade chemicals and distilled water were used throughout the study. All glassware and plastic containers used in this work were washed with detergent solution followed by 20 $\%(\mathrm{v} / \mathrm{v})$ nitric acid and then rinsed with tap water and finally with distilled water.

Sampling: Funaria hygrometrica samples were collected from five different locations within Dutsinma town in May, 2007. This include Dutsinma Market Area (DMA), Isa Kaita College of Education campus, Dutsinma (CEC), along Dutsinma-Kankia Highway (DKkH), along Dutsinma-Katsina Highway (DKtH), and Dutsinma Central Area (DCA). Only adult and healthy species were harvested. Six different samples were collected from each location, each was kept in a polyethylene bag and labeled accordingly. In the laboratory, the samples were separated from their substrates, carefully washed three times with distilled water to remove adhering particles and then dried in an oven at $75^{\circ} \mathrm{C}$ for $48 \mathrm{~h}$. Each dried sample was grounded into a fine powder, sieved and finally stored in a $250 \mathrm{~cm}^{3}$ screw capped plastic jar appropriately labeled (Audu and Lawal, 2005).

Method: $1.00 \mathrm{~g}$ each of the grounded sample was weighed into a digester (Mulex A20), $10 \mathrm{~cm}^{3}$ of the digestion mixture (a mixture of concentrated nitric acid and perchloric acid in ratio 4: 1) was added. The mixture was heated at $60^{\circ} \mathrm{C}$ until a yellow straw solution was obtained. Then the temperature was increased to $120^{\circ} \mathrm{C}$ until there was a complete dissolution of the sample (Batagarawa, 2000). The resulting solution was evaporated and re-dissolved in $10 \mathrm{~cm}^{3} 0.1 \mathrm{M} \mathrm{HNO}_{3}$. The solution was then filtered through an acid washed Whatman filter paper into a $50 \mathrm{~cm}^{3}$ volumetric flask and then diluted to the mark with water.

Metal concentrations were determined by atomic absorption spectrophotometer ( Buck Scientific Model 210 VGP) equipped with a continuum source background correction and attached to an IBM computer. The results of each were the average of ten sequential readings (Ayodele and Abubakar,1998). Results are given in ugg- $^{1}$ of the dry mass. Samples were analyzed for $\mathrm{Cd}, \mathrm{Cu}, \mathrm{Fe}, \mathrm{Mn}, \mathrm{Ni}, \mathrm{Pb}$ and $\mathrm{Zn}$ under optimized instrument conditions.

\section{RESULTS AND DISCUSSION}

Table 1 shows the mean concentrations of metals in the samples of Funaria hygrometrica analyzed from various locations in Dutsinma town.

Table 1: Mean Metals Concentration in Funaria hygrometrica

\begin{tabular}{|l|l|l|l|l|l|l|l|}
\hline $\begin{array}{l}\text { Sample } \\
\text { Locations }\end{array}$ & \multicolumn{7}{|c|}{ Metal Concentration $\left(\mu g^{-1}\right)$} \\
\hline & $\mathrm{Cd}$ & $\mathrm{Cu}$ & $\mathrm{Fe}$ & $\mathrm{Mn}$ & $\mathrm{Ni}$ & $\mathrm{Pb}$ & $\mathrm{Zn}$ \\
\hline $\mathrm{DMA}$ & $0.19 \pm 0.02$ & $3.87 \pm 0.40$ & $131.48 \pm 23.05$ & $7.17 \pm 0.84$ & $0.11 \pm 0.02$ & $3.03 \pm 1.86$ & $5.64 \pm 1.12$ \\
\hline $\mathrm{CEC}$ & $0.06 \pm 0.01$ & $1.45 \pm 0.32$ & $92.72 \pm 15.06$ & $4.13 \pm 0.29$ & $0.05 \pm 0.01$ & $1.17 \pm 0.57$ & $3.82 \pm 0.95$ \\
\hline DKkH & $0.43 \pm 0.03$ & $3.54 \pm 0.58$ & $96.77 \pm 35.01$ & $5.43 \pm 0.78$ & $0.13 \pm 0.01$ & $3.93 \pm 1.37$ & $6.28 \pm 1.69$ \\
\hline DKtH & $0.31 \pm 0.08$ & $4.97 \pm 1.58$ & $106.45 \pm 27.05$ & $6.63 \pm 0.81$ & $0.16 \pm 0.02$ & $6.40 \pm 1.27$ & $7.94 \pm 1.06$ \\
\hline DCA & $0.12 \pm 0.02$ & $2.77 \pm 0.60$ & $81.75 \pm 19.32$ & $9.64 \pm 0.54$ & $0.08 \pm 0.01$ & $2.62 \pm 0.89$ & $4.31 \pm 1.33$ \\
\hline
\end{tabular}

KEY: DMA = Dutsinma Market Area $;$ CEC = College of Education Campus $;$ DKkH = Dutsinma- Kankia Highway

DKtH $=$ Dutsinma-Katsina Highway; DCA = Dutsinma Central Area

The results show a general trend in the concentrations of the metals in all the plant samples analyzed. They were present in the order, $\mathrm{Fe}>\mathrm{Mn}>\mathrm{Zn}>\mathrm{Pb}>\mathrm{Cu}$ $>\mathrm{Cd}>\mathrm{Ni}$ (Figs. 1 and 2). This correlated with similar studies (Pennington et al, 1995; Onianwa et al, 2001). $\mathrm{Fe}$ was highest in concentration; $\mathrm{Cd}$ and $\mathrm{Ni}$ were lowest while $\mathrm{Mn}, \mathrm{Zn}, \mathrm{Pb}$ and $\mathrm{Cu}$ had intermediate values. Generally, the mean concentration of $\mathrm{Cd}$ ranged from $0.06 \mu \mathrm{gg}^{-1}$ in CEC to $0.43 \mu \mathrm{gg}^{-1}$ in DKkH samples. The mean concentration range of $\mathrm{Cu}$ was $1.45 \mu \mathrm{gg}^{-1}$ to $4.97 \mu \mathrm{gg}^{-1}$ with the highest concentration obtained in DKtH while the lowest concentration was obtained in CEC samples. The mean concentration of $\mathrm{Fe}$ ranged from $81.75 \mu \mathrm{gg}^{-1}$ to 
$131.48 \mu \mathrm{gg}^{-1}$ with the highest concentration recorded in DMA samples and the lowest in DCA's. The mean concentration of $\mathrm{Mn}$ ranged from $4.13 \mu \mathrm{gg}^{-1}$ to $9.64 \mu \mathrm{gg}^{-1}$ with the highest concentration obtained in DCA and the lowest in CEC samples. The mean concentration range of $\mathrm{Ni}$ was from $0.05 \mu \mathrm{gg}^{-1}$ in CEC to $0.16 \mu \mathrm{gg}^{-1}$ in DKtH samples. The mean concentration range of $\mathrm{Pb}$ was from $1.17 \mu \mathrm{gg}^{-1}$ in CEC samples to $6.40 \mathrm{\mu gg}^{-1}$ in the samples from DKtH. And the mean concentration of $\mathrm{Zn}$ ranged from $3.82 \mu \mathrm{gg}^{-1}$ in CEC samples to $7.94 \mu \mathrm{gg}^{-1}$ in the samples from DKtH (Figs. 1 and 2).

Many authors have reported high concentration of $\mathrm{Fe}$ in different moss species (Onianwa and Egunyomi, 1983; Schilling and Lehman, 2002; Zechmeister et al., 2005). The concentration of $\mathrm{Fe}$ in this study is about 16 times higher than that of $\mathrm{Zn}$ and $\mathrm{Mn}$. The high

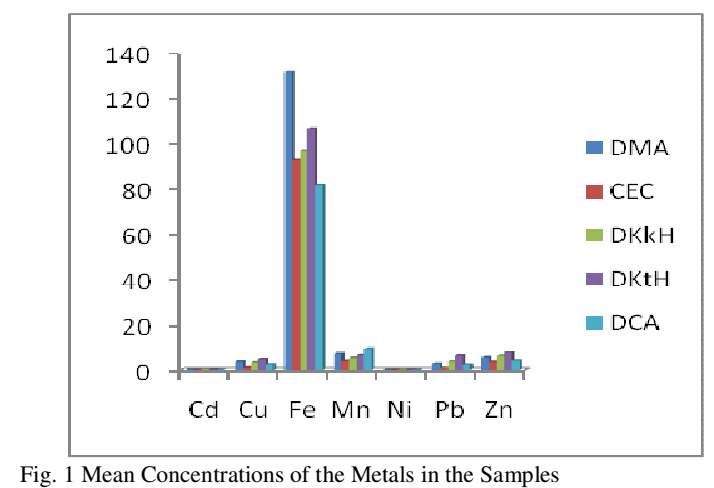

Conclusion: The mean concentration of heavy metals in Funaria hygrometrica harvested in Dutsinma town allowed for the determination of the metals fallout in the area. The significant levels of copper, zinc, and lead obtained from samples from the highway sites and the market area is an indication of their concentrations in the atmosphere, as a result of both vehicular and industrial emissions. The low concentrations of cadmium and nickel suggest low contributing factors to their spread and as well as the plants inability to preferentially accumulate these metals.

\section{REFERENCES}

Aceto, M; Abollino, A; Conca, R; Malandrino, M; Mentasti, E; Sarzanini, C (2003). The use of mosses as environmental metal pollution indicators. Chemosphere 50, 333-342.

Ademoroti, CMA (1996). Environmental Chemistry and Toxicology. Foludex Press Ltd. Ibadan. 171-201. concentration of $\mathrm{Fe}$ in moss plant has been attributed to the high polyuronic acid content of its cell wall (Batagarawa, 2000) besides the relative abundance of the metal in the earth's crust. Significant concentrations of $\mathrm{Zn}, \mathrm{Cu}, \mathrm{Pb}$ and $\mathrm{Ni}$ from the samples of moss plant obtained from DKtH, DKkH and DMA can be attributed to industrial and automobile emissions (Kord et al, 2010; Viard et al., 2004). Relatively low concentrations of metals were reflected by the samples obtained from the College of Education campus (CEC) Figs. 1 and 2. This could be attributed to the location of this college in a remote area from the town, coupled with low commercial and vehicular activities within the campus. However, the fact that there are higher concentrations of metals in the samples of mosses obtained from the vicinity of the two busy highways and market area suggests high aerial metal pollution at these locations.

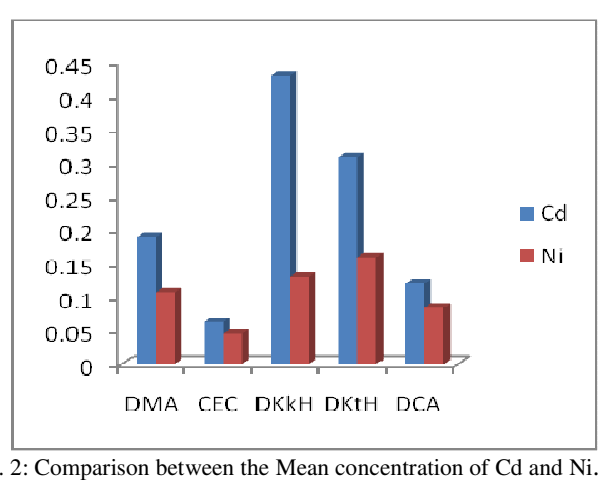

Audu, AA; Lawal, AO (2005). Variation in Metal Contents of Plants in Vegetable garden sites in Kano Metropolis. J. Applied Sci. and Environ. Manage., 10(2): 105-109.

Ayodele, JT; Ahmed, A (1996). Monitoring air pollution in Kano by chemical analysis of scouts pine (Pinus sylvetris L) needle for heavy metals. J. Chem. Soc. Nigeria 21: $81-86$.

Batagarawa, SM (2000). Funaria hygrometrica as bio - indicator of heavy metals in Kano, Kano State Nigeria. An M. Sc. Thesis submitted to P. G. School, Bayero University Kano, Nigeria.

Csintalan, Zs; Juh $¥ s z, A$; Benk, ${ }^{\mathrm{TM}}$ Zs; Raschi, A; Tuba, Z (2005). Photosynthetic responses of forest-floor moss species to elevated $\mathrm{CO}_{2}$ level by a natural $\mathrm{CO}_{2}$ vents. Cer Res Com 33:177180.

Fernandez, JA ; Ederra, A ; Nunez, E; MartinezAbaigar, $\mathrm{J}$; Infante, $\mathrm{M}$; Heras, $\mathrm{P}$; Elias, $\mathrm{MJ}$; 
Mazimpaka, V; Carballeira, A (2002). Biomonitoring of metal deposition in northern Spain by moss analysis. The Sci. Tot. Environ. 300: 115-127.

Gerdol, R; Bragazza, L; Marchesini, R; Alber, B; Bonetti, L; Lorenzoni, G; Achilli, M; Buffoni, A; De Marco, N; Franchi, M; Pison, S; Giaquinta, S; Palmieri, F; Spezzanno, P (2000). Monitoring of heavy metal deposition in Northern Italy by moss analysis. Environ. Pollut. 108: 201-208.

Kasanen, P; VenetVaara, FT (1991). Comparison of biological collection of airborne heavy metals near ferrochrome and steel work. Water Air and Soil Pollut., 60: 337-359.

Kho, FWL.; Law, PL; Ibrahim, SH; Sentian, J (2007). Carbon monoxide levels along roadway. Int. J. Environ. Sci. Tech., 4 (1) : 27-34

Kord, B; Mataji, A; Babaie, S (2010). Pine (Pinus Eldarica Medw.) needles as indicator for heavy metals pollution. Int. J. Environ. Sci. Tech., 7 (1) : 79-84,

Meenks, JLD; Tuba, Z (1991). Bryophytes as biological indicators. -In: Biological indicators in environmental protection, Kov $\neq c s$ M, ed., Ellis Horwood Ltd. Publ., AkadŽmiai Kiad-, Chichester Đ Budapest, pp. 169-191.

Naveh, Z; Steinberg, EH; Chaim, S (1979). The use of bio-indicators for monitoring of air pollution by fluorine, ozone and sulphur dioxide: In Environmental Bio-monitoring, Assessment, Prediction and Management of certain case studies and related Quantitative issues. Ed.
Cains, G.I.P. and Waters, W.E. International Cooperative Publishing House, Fatiland, USA. Pp21-47.

Onianwa, PC (2001). Monitoring atmospheric metal pollution: a review of the use of mosses as indicators. Environ. Monit. and Assess. 71: 1350

Onianwa, PC; Adaeyemo, AO; Idowu, EO; Ogabiela, EE (2001). Copper and Zinc contents of Nigerian foods and estimates of the adult dietary intakes. J. Food Chem. 72: 89-95.

Onianwa, PC; Egunyomi, A (1983). Trace metal levels in some Nigerian mosses used as indicators of atmospheric Pollution. Environ. Pollut. Series B. $171-81$.

Pennington, JAT; Schoen, SA; Salmon, GD; Young, B; John, RD; Mart, RW (1995). Composition of core foods of the USA food supply 19821991. J. Food Compos. Anal. 8(2): 129-169.

Schilling, JS; Lehman, ME (2002). Bioindication of atmospheric heavy metal deposition in the Southeastern US using the moss Thuidium delicatulum. Atmos. Environ. 36:1611-1618.

Viard, B; Pihan, F; Promeyrat, S; Pihan, JC (2004). Integrated assessment of heavy metal $(\mathrm{Pb}, \mathrm{Zn}$, Cd) highway pollution: bioaccumulation in soil, Graminaceae and land snails. Chemosphere, 55 (10): 1349-1359.

Zechmeister, H; Hohenwallner, D; Riss, A; HanusIllnar, A (2005). Estimation of element deposition derived from road traffic sources by using mosses. Environ. Pollut. 138: 238-249. 